\title{
BORDER THINKING AND FEMINIST SOLIDARITY IN THE FOURTH WORLD
}

\author{
Martha Nandorfy \\ University of Guelph
}

Borders and bridges, the recurring metaphors for separation and difference on the one hand, solidarity and co-implication on the other, provide the framework for thinking about the political, social and cultural effects of globalization and resistance. Border thinking, then, is a bridge, and first emerged in response to the "low impact conflict" euphemistically and militaristically referring to the violence along the Mexican/US border, extending to any area where Mexican Americans and Anglo-Americans co-exist and clash. Gloria Anzaldúa, the Chicana author of Borderlands/La Frontera: The New Mestiza, fuses the historical, geographical, and cultural divide and incarnates this wound in her own body. She represents the border as a «1,950 mile-long open wound / dividing a pueblo, a culture, / running down the length of my body, / staking fence rods in my flesh, / splits me splits me / me raja me raja / This is my home / this thin edge of / barbwire» (3). But the border cannot completely circumscribe the imagination... The manmade wound inscribed on nature is unstable, a fleeting imposition of power.

In her most recent book Feminism Without Borders: Decolonizing Theory, Practicing Solidarity, Chandra Talpade Mohanty persuades us to think likewise beyond borders; giving an ironic twist to the anti-globalitarian vision predicated on capitalist hegemony, she insists that «our minds must be as ready to move as capital is, to trace its paths and to imagine alternative destinations» (251). Anzaldúa's poem affirms that bodies, human and natural, are inter-dependent and will not be separated or stopped from relating to each other: «But the skin of the earth is seamless. / The sea cannot be fenced, / el mar does not stop at borders. / To show the white man what she thought of his arrogance, / Yemaya blew that wire fence down" (3). The African goddess of life and love embodied in the sea suddenly appears on the Mexican / US border, and why not? She is revered in the Caribbean and once she is imaginatively associated with the sea's feminine power, she can blow as far as the desert in order to liberate her daughter. Next Anzaldúa invokes the pachakuti, also known as koyaaniskatsi, and the Seventh Fire, at once revolution and 


\section{BORDER THINKING AND FEMINIST SOLIDARITY IN THE FOURTH WORLD}

apocalypse prophesied by indigenous cultures throughout the Americas: «This land was Mexican once, was Indian always / and is. / And will be again" she prophesies enigmatically, after which she calls herself «un puente tendido» [a stretched out bridge]. Her body is split by a gaping wound, and simultaneously is the bridge reaching from «el mundo gabacho al del mojado» [from Whitc America to the wetback's world]'.

This kind of bridge is not a happy rainbow connecting two equal communities in a harmonious relation; instead, it extends between communities conceived of as dynamic and hybrid in nature, but also torn by disparity and prejudice. This gendered, racialized, and classed expression of multiculturalism will be the dominant (dis)ordering principle of my essay: in terms of aesthetics, ethics, politics, and prophecy. Given the wealth of cultural material that I have come across in my research on radical multiculturalism, I propose to do a comparatist reading of a selection of Chicana and Chicano writers who straddle the border in very different ways. The transnational feminisms of Chandra Talpade Mohanty and Trinh Minh-ha provide the theoretical framework for both my interpretation of these texts, and the larger pedagogical concerns associated with creating curricula that decolonize theory and promote liberation ${ }^{2}$. The combination of Chicana/Latina Studies and Women's Studies is the kind of curricular strategy recommended by Mohanty, who says that such alliances ensure the survival of programs in which questions of power, history, and self-identity matter more that disciplinary parameters $(195,199)$. I would qualify this statement by stressing that disciplinary parameters must be crossed in order to change how we teach about the West and its others.

The border perspective has clear academic implications, especially for departments that are striving to enrich curriculum and cultural pedagogy by recognizing that a canon dominated by straight, white, male, anglophone writers is exclusionary and undemocratic in its denial of the ever increasing multiculturalism characterizing North America and Europe. Multiculturalism -meaning the truly diverse demography and cultural practices of shape-shifting, hybrid communities- tends to be reduced by institutions to the museum piece tokenism of the exotic, which in the very same process, by way of de-historicizing differences, guarantees the absorption of difference into a painless cultural pluralism. Rosaura Sanchez accuses US universities of instituting ethnic studies programs in the late 1960's with the self-serving and defensive objective of quelling student protests thereby ensuring «that university research and business could be conducted as usual» ("Ethnicity, Ideology \& Academia" quoted in Mohanty 198).

In the academy, this neutralization of culture, symptomatic of ongoing colonization, is often perpetrated and simultaneously camouflaged through the incorporation of so-called multicultural texts into the mainstream canon that is not viewed as one among "multi" cultures, but stands rather as the dominant white canvas (neutral and innocently, unhistorically white); a canvas or perhaps

\footnotetext{
1.- The Quechua word "pachakuti" means an overturning of the world, while the Hopi word "Koyaaniskatsi" means "life out of balance" or "a state of life that calls for another way of living", a stage that relates to the Fourth World that according to Hopi cosmogony we currently inhabit; a world that will be destroyed through the misuse of such technology as atomic power. The concept of the Seventh Fire seems to coincides with the Seven Worlds through which we journey according to Hopi belief, but according to the Anishinabe (sometimes referred to as Ojibway), we are currently living in the time of the Seventh Fire which will light the Eight Fire only if people of European descent choose the right path. If they choose to continue on the wrong path, then the destruction that they are so good at wrecking will turn on them.

2.- Trinh T. Minh-ha is a filmmaker, writer and composer of Vietnamese descent and is currently Professor of Women's Studies, Film Studies and Rhetoric at the University of California, Berkeley. She brings a non-Western perspective to discussions of identity, and a unique way of writing about complex theoretical issues with an Eastern sensibility that enacts a powerful challenge to logocentric theory, through poetic and paradoxical discourse and storytelling. Her reflections on cultural identity, gender politics, anthropological othering of the Majority World, and storytelling traditions provide valuable insights into the study of hybrid and non-canonical cultural expression generally.
} 


\section{MARTHA NANDORFY}

a palimpsest that keeps trying to wipe itself clean although recently it tolerates a few splashes of colour and queer cryptic messages. These ex-centric representations often occupy a kind of niche status and are systematically discredited by influential academics like Allan, Bloom and others, who claim that the growing interest in pluralistic culture is a mere fad, a kind of degenerate fascination with special interest groups that are viewed as a threat to both national and universal integrity. Mohanty, on the other hand, claims that feminist methodologies anchored in «the lives of marginalized communities of women provide the most inclusive paradigm for thinking about social justice» and that the "particularized viewing» of universal justice «is the very opposite of special interest thinking» (Mohanty 231). Echoing this vision of the inclusive paradigm, Trinh Minh-ha says: «dominated and marginalized people have been socialized to see always more than their own point of view. In the complex reality of postcoloniality it is therefore vital to assume one's radical "impurity" and to recognize the necessity of speaking from a hybrid place, hence of saying at least two, three things at a time» (Framer Framed 140).

Before going any further, let us consider the geographic borders separating and connecting Mexico and the US just before the signing of the "Treaty of Guadalupe Hidalgo" in 1848. 525,000 square miles of Mexican territory spanning the states of present-day Arizona, California, western Colorado, Nevada, New Mexico, Texas and Utah became US territory. Americans viewing a map outlining the border lines prior to the treaty discover that maybe Spanish isn't even a foreign language, maybe isn't just useful for tourism or NAFTA business. Anzaldúa explains that «in the 1800 's, Anglos migrated illegally into Texas, which was then part of Mexico, in greater and greater numbers and gradually drove the tejanos from their lands, committing all manner of atrocities against them [...] later in 1836, Texas became a republic. Tejanos lost their land and, overnight, became the foreigners» (1987: 6-7). With the victory of the US forces in the US/Mexican War, los norteamericanos pushed the Texas border down 100 miles. The treaty of Guadalupe Hidalgo «left 100,000 Mexicans citizens on this side, annexed by conquest along with the land. The land established by the treaty as belonging to Mexicans was soon swindled away from its owners. The treaty was never honored and restitution, to this day, has never been made» (1987: 7). So, while today most Mexican-Americans are immigrants from Mexico, many others are third and fourth generation US citizens. According to Carlos Fuentes, «It is perhaps an act of poctic justice that now the Hispanic world should return, both to the United States and to part of its ancestral heritage in the Western Hemisphere" (343). Fuentes' use of "Hispanic" may refer to the spread of Spanish as a second language, however unofficial, but this term ignores the issue of race. As Anzaldúa reminds us, «For every gold-hungry conquistador and soul-hungry missionary who came north from Mexico, ten to twenty Indians and mestizos went along as porters or in other capacities. For the Indians, this constituted a return to the place of origin, Aztlán, thus making Chicanos originally and secondarily indigenous to the Southwest» (1987: 5).

Richard Rodriguez, who has been called «the most renowned Chicano interpreter of the Pacific Rim» (Saldívar 146) makes race the primary focus of his latest book of essays entitled Brown: The Last Discovery of America. In one instance, Rodriguez's scrutiny of racial tensions between Latinos and African-Americans takes the form of a dialogue between himself and Darrell, a friend who calls himself "black", and wants to know how Rodriguez responds to the question: «What are you?», to which Rodriguez. replies: «I don't». Darrell counters: «Yes you do. You say, queer Indian Catholic-some sidestep bullshit like that» (Rodriguez 136-37). For his part, Darrell accepts the «one-drop notion» in calling himself "black" because that's how cops sec him, suggesting that identity however shifting, indeterminate, or mistaken, is in the eye/I of the other.

Chapter five of Rodriguez's book is entitled "Hispanic" and opens with a dictionary definition of this term: "1. Spanish, adj. 2. Latin American, adj. 3. Hispano, noun. An American citizen or resident of Spanish descent». The definitions then spin out of control to describe wildly divergent perspectives and experiences that consequently make a joke of defining people in one word. Definition 4. reads: «Ducking under the cyclone fence, noun. 5. Seen running from the 
scene of the crime, adj. Clinging to a raft off the Florida coast. Elected mayor in New Jersey. Elevated to bishop or traded to the San Diego Padres» and so on (103). If this is the case, then why does Rodriguez bother to dedicate a chapter to this ethnic label? He makes it clear that the term originates from a governmental statistical directive and was coined during Nixon's administration by Anglos who felt compelled to organize people into what Rodriguez refers to as the unglamorous American fair: composed of 5 categories: Black, White, Asian/Pacific Islander, Native American/ Eskimo, and Hispanic (105). Spatially represented as drafty rooms or pavilions erected on a fairground, Rodriguez remarks on how «Mayan Indians from the Yucatán were directed to the Hispanic pavilion» described as "(Spanish colonial), which they must share with Argentine tangoists, Colombian drug dealers, and Russian Jews who remember Cuba from the viewpoint of Miami» (105). Though it is clear that Rodriguez finds the term inadequate to the point of being meaningless, he reveals his halfhearted participation in promoting both the idea of a Hispanic identity, and himself as a public speaker who survives and gains recognition by delivering what Anglo-America wants to hear. He succinctly represents his role as cultural ambassador, playing a public game: «I take my collapsible double-irony on tour to hotel ballroom conferences and CSPAN-televised luncheons and "Diversity Week" lectures at universities. For a fee, I rise to say I am not Latin American, because I am Hispanic. I am Hispanic because I live in the United States. Thank you. (For a larger fee, I will add there is no such thing as a Hispanic. Thank you)» (104). We can assume that he isn't often offered the larger fee, because the whole premise of this chapter is his incessant research and writing on a topic that he is commissioned to publish on, yet considers a farce. Rodriguez, however, enjoys farce; what he can't stand is Puritanism, the denial of farce.

Instead of complaining about how his success as a writer results, at least partially, from being exploited as a token ethnic commentator, Rodriguez, armed with his "collapsible double-irony" is continually on the road giving official public tolerance speeches, which he then turns inside out in his private/published reflections. Is this a cynical game? Perhaps it is part cynicism, part survival tactic, and part coherent mediation of his brown self in a society that -after 500 years- is still bent on discovery.

The subtitle of Rodriguez's preface is "BROWN AS IMPURITY" and I'll quote the opening paragraph in which he clearly states his thesis:

I write of a color that is not a singular color, not a strict recipe, not an expected result, but a color produced by careless desire, even by accident; by two or several. I write of blood that is blended. I write of brown as complete freedom of substance and narrative. I extol impurity. I eulogize a literature that is suffused with brown, with allusion, irony, paradox -ha!- pleasure. I write about race in America in hopes of undermining the notion of race in America (xi).

These lines are representative of Rodriguez's attitude, style, his commitment to theatricality, his sustained attack on Puritanism (whether WASP, African-American, or Native). They are also symptomatic of his lack of hindsight; we may well wonder how pleasurable or accidental the first acts of mestizaje were during the Conquest and colonization with its plantation economy wholly dependent on slave labour. Whose desire would be satisfied in circumstances dominated by European landlords and overseers when most of the women present were African and Amerindian slaves? Rodriguez prefers to forget the past and to view the world from an individualistic and somewhat solitary perspective. He rarely invokes any sense of community, yet manages to infuse the topic of race with a highly personal libidinal force that is undeniably social in its attraction to the other. He sets his position against those «who take "race" for a tragic noun, a synonym for conflict and isolation" (xv). And despite recollections of violence against him even as a child on the basis of being identified as Mexican or Native, he asserts that "race" is not such a terrible word for him and speculates: «Maybe because my nature is already mixed. The word race encourages me to remember the influence of eroticism on history. For that is what race memorializes. Within any discussion of race, there lurks the possibility of romance» (xv). 


\section{MARTHA NANDORFY}

Rodriguez is hopelessly romantic, sensual, playful, and insightful. He is also myopic in what Mohanty would classify as a prototypically Western way; meaning that he is very selective about when and how he looks at disparity, social injustice, collective memory, cultural disjunctions, and tends to write out of his largely unexamined position of privilege. According to Mohanty «it is important to always foreground not just the connections of domination but those of struggle and resistance as well» (243). Rodriguez's examination of identity dehistoricizes race and represents his gay orientation as devoid of struggle thanks to the art of dissemblance and parody.

Is it possible to dissect a person's sensibilities from his or her, intuitions, humour, desires, into discrete categories that are supposedly causes, identity markers labeled "gender", "sexual orientation", "race", "ethnicity", "class", etc., causes that produce certain effects? I think not. Writing about "Pedagogies of Dissent", Mohanty observes that «the implicit definition of experience is important. Experience is defined as fundamentally individual and atomistic, subject to behavioral and attitudinal change. Questions of history, collective memory, and social and structural inequality as constitutive of the category of experience are inadmissible within this framework» (209). Mohanty is here describing what she considers to be characteristic of Western individualism, and Rodriguez's discourse on race and sexuality reflects these very limitations. The seductive power of his discourse lies in its intimate, subjective tone; the absence of theoretical language is refreshing, but Mohanty's definition of theory sheds light on why Rodriguez's writing enjoys mainstream success and is unsatisfying in its desire to accommodate instead of contest. According to Mohanty, «theory is a deepening of the political, not a moving away from it: a distillation of experience, and an intensification of the personal. [...] This kind of theoretical, analytical thinking allows us to mediate between different histories and understandings of the personal» (191).

Instead of thinking about historical agency in order to build solidarities across divisive borders as envisioned by Mohanty, Rodriguez playfully reduces the notion of solidarity to eroticism. In answer to what he characterizes as the typical question asked by French CBC radio and TV: «Are Hispanics in the Southwest destined to forge some sort of new Quebec?» Rodriguez responds categorically: «Nope, madame. And here's why: Though Hispanics, particularly Chicanos in the Southwest -the noisiest among us- made their reputations "against" assimilation, Hispanics nevertheless trust most the ancient Spanish pronoun, the first-person plural pronoun, the lovepotion pronoun -nosotros. We. Try as we will to be culturally aggrieved by day, we find the gringos kind of attractive in the moonlight» (163-64).

Rodriguez dedicates a few pages to multiculturalism in Canada, since as he observes, «American politicians, American classrooms turn to Canada for an idea of orderly civic life» (162). While he opposes any official meddling in cultural erotics, including the melting pot which many people of colour lament saying that they stick to the bottom as brown sludge instead of bubbling to the surface, he is equally suspicious of «the favored metaphor of multicultural Canada, the "mosaic" -separate units; composite by satellite-» which according to Rodriguez promotes «a most unerotic notion of society" (163). His general perspective on Canada is shockingly mainstream, hegemonic to the point of denying our existence: «Canada has never been much of an idea for Americans. We like Canada. Our good neighbor. Never hear them. Tidy... It interests Americans that Canada is clean and empty and unimplicating; the largest country in the world that doesn't exist» (161). I guess we have our post-Trudeau politicians to thank for this representation of our inconsequential goodness in relation to the US. I very much doubt that Rodriguez has ever attended a summit meeting here, or has seen an episode of CODCO or Rick Mercer's merciless interviewing of supposedly educated US citizens on Canadian or international affairs, our private little parody of 


\section{BORDER THINKING AND FEMINIST SOLIDARITY IN THE FOURTH WORLD}

American ignorance, smugness, innocence, amnesia ${ }^{3}$. What strikes me as most disturbing about Rodriguez's portrayal of Canada is the utter lack of border thinking.

Speaking about NAFTA, Rodriguez once again imposes US cultural hegemony, implying that Canada and Mexico meet face to face for the very first time: «Haut shook hands with Sur. A vertical alignment, yes, but Nafta signified more than a meeting of basement and balcony. The surprise was mezzo. President William Jefferson Clinton rose to welcome Canada and Mexico into -and here he quotes Clinton-, into "the American future"» -partially satirized by Rodriguez as "words blazing like northern lights on an Eskimo Pie packet» (158). But doesn't that refer to Canada? Why no comment of what a tripartite American future means?! Can it possibly refer to the beginning of a Pan-American future? Rodriguez. continues by saying that while the future used to lie westward, it is now recalibrated to north and south, and that "We (referring here to Unitedstatians) will need a vocabulary appropriate to people of the middle» $(158)^{4}$. Middle? Is that like "centre", "centre of the universe", "middlemen"? This is exactly what we discussed long ago in a meeting between Canadians and Mexicans in Calgary; Rodriguez is wrong: I was there at an international conference in Calgary where worried Canadians and Mexicans met (and not even for the first time) to discuss the dangers of NAFTA, the verdict according to many being that the US would function as the middleman in an economy designed to exploit Canadian and Mexican natural resources and cheap Mexican labour. Rodriguez doesn't go there, but I'm reminded of a Canadian painting by artist Greg Curnoe of an imaginary map of which I have posteard versions that Cubans always ask me for; it represents North America as Canada bordering directly on Mexico, the Caribbean right where it was the last time I looked, and part of Central America. No middle here. But again the problem with that image -whether representative of wishful thinking, or an incitement to start marching; Canadians southward, Mexicans northward to a truly historical meeting-the problem is a lack of border thinking. Rodriguez erases Canada; Curnoe erases the US.

Guillermo Gómez-Peña is a Spanish-speaking Mestizo, Chilango who since leaving Mexico City to live in California calls himself a Chicano. He is a radical performance artist who has worked with Coco Fusco and many other Latinas and Latinos on both sides of the border, and right on the border much to the chagrin of the Border Patrol. While his work is little known in academic circles and ignored by transnational media, it reaches crowds of astonished spectators who happen to be in the right place at the right time to catch one of his impromptu performances about colonialism in its myriad manifestations, past and present. Gómez-Peña describes himself as having a kaleidoscopic identity. Some of the border personae into which he slips in and out of with great ease and coherence include Border Brujo, Warrior for Gringostroika, and Naftazteca.

3.- " "CODCO" was a Newfoundland and Labrador Canadian troupe that aired on CBC from 1988-1992... CODCO draws on the province's cultural history of self-deprecating "Newfie" humour, frequently focusing on the cod fishing industry... CODCO's pointed satire takes aim at regional differences, national assumptions, politics, sexism, gender roles, gay codes and television genres... The CODCO members' theatrical roots trained them to shape detailed caricatures, with nuances that dismantle not only conventions of the source personas and genres but also the ideologies of a medium colonized by commercialism” (http://en.wikipedia.org/wiki/CODCO).

Rick Mercer, also from Newfoundland, has received 20 Gemini awards for writing and performing in the TV programs This Hour has 22 Minutes and Made in Canada. He created and co-produced a CBC special Rick Mercer's Talking to Americans and the most recent series Monday Report. These programs have carned him the distinction of being considered by many to be "Canada's Unofficial Opposition". «He understands what amuses, delights, and occasionally enrages Canadians about our politicians, our media elite, and our great neighbour to the south» according to the I avin Agency (http://www.thelavinagency.com/canada/rick mercer.html).

4.- I have come across only one instance of the term "Unitedstatian" to refer to Americans in The Real Thing: Testimonial Discourse and Latin America. This new denomination is an effort to relinquish the name that the US appropriated from all the other inhabitants of the Americas. As the editor Georg Gugelberger points out, «it is obviously drawn from the Spanish estadounidense" and is developed by Michael Kearney in "Borders and Boundaries of State and Self at the End of Empire" (19). 


\section{MARTHA NANDORFY}

Instead of advocating either the destruction or the hegemony of the US, Gómez-Peña accepts that we all straddle the border, with, as he says, one foot in Armageddon and the other in Utopia (1989: 55). In a mini-dictionary he offers his readers to navigate through his essays and partially scripted video art, entitled "Glossary of Borderismos" he gives the following definition of the term "gringostroika": «A continental grassroots movement that advocates the complete economic and cultural reform of US anarcho-capitalism" and under the term "borderization" the definition reads: «Self-explanatory. Currently afflicting the US and Western Europe, this process is also known by sociologists as "Calcuttization" or "tercermundización"» (1996: 242, 240). In another apocalyptic/utopian encyclopedic text entitled "End-of-the-Century Topography Review" he gives definitions for five different historico-geographical spaces from the First to the Fifth World. The Fourth World, to which I refer in the title of my paper, is the utopian end of border thinking and is defined as «a conceptual place where the indigenous inhabitants of the Americas meet with the deterritorialized peoples, the immigrants, and the exiles; it occupies portions of all the previous worlds» (1996: 244).

While theorizing about border culture and border thinking by Chicanos originated in the American southwest, Gómez-Peña, like Azaldúa and Mohanty, affirms that we all inhabit the border, which is everywhere that different cultures co-exist. Like most Latinos and Latin Americans, he insists that America is not the US but rather an intercultural terrain that should always be pronounced in the plural: the Americas (1989: 32). Like Rodriguez, Gómez-Peña denies the possibility of ethnic purity or "authentic" cultural identity as reactionary thinking equally characteristic of Mexican, Chicano, and white supremacist bigots. Furthermore, he affirms that true multiculturalism (the very core of our new society [1989:52]) is the postmodern reality of the conquered since 1492 (García 15), and that multicultural communities are primarily composed of the poor, homeless, unemployed, prisoners, people living with AIDS, soldiers returning from the Gulf War -a brutally frank representation that has little in common with what we in Canada celebrate as multiculturalism at official events that highlight not human rights, but new cuisines and world beat music. This sort of festival of mosaics and tapestries, he dubs with the ironically scrambled term: "culti-multuralism" defined in his "Glossary of Borderismos" as «An esperantic Disneyworldview in which all cultures, races and sexes live happily together» (1996:241) similar to the images he identifies as the false Utopia of Benetton ads which he associates with «refried colonial ideas", and the naïve notion that all is well, if we link arms and dance the mambo together:

Gómez-Peña's globalization-from-below diverges significantly from Rodriguez's tongue in cheek but unexamined reference to an ambivalent American future. He not only acknowledges Canada's existence, he has initiated activist art projects traversing all of North America. In the summer of 1989 the collective named "Border Arts Workshop/Taller de Arte Fronterizo" undertook a transnational event entitled "Border Axis" which he describes as follows: «Through fax machines, an 800-telephone line, and mail, we created a temporary network between twelve cities in three countries: the US, Canada, and Mexico. We exchanged information with groups of artists and activists dealing with issues such as immigration, human rights, censorship, AIDS, and abortion. We also declared the space a Chicano cultural center and made all our resources available to local groups» (1989: 28).

This productive inter-relation between the local and the global is also a cornerstone of Mohanty's comparatist feminism. She asserts that «differences are never just differences. In knowing differences and particularities, we can better see the connections and commonalities because no border or boundary is ever complete or rigidly determining. The challenge», according to Mohanty, «is to see how differences allow us to explain the connections and border crossings better and more accurately, how specifying difference allows us to theorize universal concerns more fully. It is this intellectual move», says Mohanty, that enables «women of different communities and identities to build coalitions and solidarities across border» (226). 


\section{BORIDER THINKING AND FEMINIST SOLIDARITY IN THE FOURTH WORLD}

While Gómez-Peña admits that the "Border Arts Workshop" eventually suffered the same fractious tensions as the larger society -racism, opportunism, desire/fear, cultural dependency, etc. $\rightarrow(1989: 29)$, the temporary failure of this particular collective does not dampen his enthusiasm and prophetic vision. Multiculturalism, he announces, is the funeral of modernism and the birth of a new culture. Border culture is inevitably fraught, hence, easily distinguishable from Benetton ads or global villages where half-naked tribesmen surf the net on IBM laptops.

Gómez-Peña's manifesto of border culture is comprised of about twenty paragraphs each starting with the words «But it also means...» This text not only sets out the spiritual and ideological breadth of a new cartography -the democratization of the East; the socialization of the West; the ThirdWorldization of the North and the First-Worldization of the South-, it also enacts multilingualism, in poetic and performative discourse, that fuses radical politics and prophecy, thereby implicating the reader in a participatory event. The manifesto opens by stating that «border culture is a polysemantic term» implying not just ambiguity or heterogeneous realities, but the need to transgress the law. The next paragraph mixes English and Spanish since he asserts further on that border culture «also means to be fluid in English, Spanish, Spanglish, and Ingleñol, cause Spanglish is the language of border diplomacy» (1989: 42). «Border culture means boycott, complot, ilegalidad, clandestinidad, contrabando, transgresión, desobediencia binacional; en otros [sic] palabras, to smuggle dangerous poetry and utopian visions from one culture to another, desde allá, hasta acá. But it also means to maintain one's dignity outside the law» (1989: 42). The reader's willingness to try to follow the text is put to the test, even if s/he does not speak Spanish or Spanglish yet (and Gómez-Peña seems to presume that most conscious people will all eventually take the plunge and try to learn in order to be effective civilian diplomats). The Glossary of Borderismos includes the term "Spanglishization" with the definition: «A continental infection for which there is no cure» (1996: 244). The infection, of course, is the cure for monoculture and pretending to try to understand other cultures from a monolingual, dominant mindset. Gómez-Peña denies the existence of a dominant culture, attributing it to mere propaganda, «a meta-reality that only exits in the virtual space of the mainstream media and the ideologically and aesthetically controlled spaces of the monocultural institutions» (1989:46).

All this implies an optimistic and prophetic worldview, while also demanding the active participation of individuals who can no longer bury their heads in the sand with the excuse that neoliberal globalitarianism spells the end to the hope of change. Gómez-Peña's vision of the "New World Border" openly challenges the claims of hegemonic world order; memories are recuperated to challenge the official histories of conquerors. The American future is addressed by Gómez-Peña's accusation that the «United States suffers from a severe case of amnesia. In its obsessive quest to "construct the future", it tends to selectively forget or erase the past» (1989: 48). But he doesn't stop at the erasure in which Rodriguez flounders. Instead, he asserts that "fortunately, the so-called disenfranchised groups who don't feel part of this national project have been meticulously documenting their histories, Latinos, African Americans, Asians, women, gays, experimental artists, and non-aligned intellectuals have used inventive languages to record the other history from a multicentric perspective» (1989: 48-49).

This recuperation of collective memory in the form of a particularized people's history also characterizes Mohanty's definition of knowledge, in contrast to the Western tradition of master narratives pretending to be objective and universal. What she identifies as «one of the larger questions at stake in the academy these days are questions of self- and collective knowledge of marginal peoples and the recovery of alternative, oppositional histories of domination and struggle», «For knowledge», she says, «the very act of knowing, is related to the power of selfdefinintion». And furthermore, «this definition of knowledge is central to the pedagogical projects of fields such as women's studies, black studies, and ethnic studies» (Mohanty 195). Anzaldúa associates knowledge with border-crossing: «Every increment of consciousness, every step forward is a travesía, a crossing. I am again an alien in new territory [...] But if I escape conscious awareness, escape "knowing", I won't be moving. [...] "Knowing" is painful because after "it" 


\section{MARTHA NANDORFY}

happens I can't stay in the same place and be comfortable. I am no longer the same person I was before» (1987: 48).

This multicentric perspective is the dominant characteristic of Chicana cultural production. In order to understand how the work of contemporary Chicanas stands in relation to earlier stages in the formation of Chicano cultural identity, we need to return to the myth of origins conceived in spatial terms as Aztlán. According to legend, Aztlán is the original site, located, in what is today, Southwestern US, from where the Mexicas migrated southward to found Tenochtitlán. This identification with Mexico and especially with the pre-Columbian, indigenous past was a founding principle of Chicano cultural identity. Chicanas have had a long struggle to carve out a space for multicentric perspectives within this largely essentialist notion of identity, based on origins and, if not racial then at least, ethnic purity.

Gloria Anzaldúa and Cherríe Moraga further problematize difference in terms of gender and sexual orientation in confronting the challenge of writing as lesbian Mestizas who do not consider themselves professional writers, in a culture that inherits patriarchal biases from all sides: the Spanish, indigenous, and Anglo-American. The imposition of rigid sexual roles and exclusionary practices in Chicano culture provoke lesbian Chicanas to dismiss any facile notions of accommodation, in favour of strongly expressed dissent, that nevertheless envisions bridging the ruptures between race, ethnicity, and gender. According to Anzaldúa, «In trying to become "objective", Western culture made "objects" of things and people when it distanced itself from them, thereby losing "touch" with them. This dichotomy is the root of all violence. Not only was the brain split into two functions but so was reality. Thus people who inhabit both realities are forced to live in the interface between the two, forced to become adept at switching modes. Such is the case with the india and the mestiza" (1987: 37). In a poem entitled "Passage," Cherrie Moraga too resists the comforting dream of a stable identity anchored in Aztlán. Like Anzaldúa's performative poetic discourse in which she embodies the border in the form of a carnal wound, Moraga also identifies herself with a wound where feminist knowledge takes root. Marilyn Waring reminds us that the etymological meaning of the term "radical" is "of the root" and that to be a radical feminist therefore, implies getting to the root of things... Moraga's poem opens with an ambiguous reference to spacc: "on the edge of the war near the bonfire / we taste knowledge», after which the first stanza reads: «there is a very old wound in me / between my legs / where I have bled, not to birth / pueblos or revolutionary / concepts or simple / sucking children / but a memory / of some ancient / betrayal» (44). The mirage of Aztlán as «the desert, untouched. /. Sands swept without sweat» is rejected as a dream: «Pero, es un sueño. This safety/ of the desert». Addressing her lover and perhaps women generally, the poem continues «My country was not like that. / Neither was yours. / We have always bled / with our veins / and legs / open / to forces / beyond our control» (45).

These Chicana writers reject narrow specialization and the conceit of being an intellectual when that means working only one's brain. They do not wish to deny the physical labour and domestic responsibilities that often continue to dominate their lives even once they decide to write and publish. They write about how difficult it is to find the time to record their thoughts, and how each and every opportunity must be grasped, because even today one rarely has a room of one's own. Anzaldúa advises women of colour:

Forget the room of one's own -write in the kitchen, lock yourself up in the bathroom. Write on the bus or the welfare line, on the job or during meals, between sleeping and waking. I write while sitting on the john. No long stretches at the typewriter unless you're wealthy or have a patron -you may not even own a typewriter. While you wash the floor or clothes listen to the words chanting in your body. When you're depressed, angry, hurt, when compassion and love possess you. When you cannot help but write (1981: 170).

This bit of wisdom is contained in a letter to Third World women writers entitled "Speaking in Tongues" included in the anthology co-edited with Cherríe Moraga This Bridge Called my 
Back, published by Kitchen Table Press. These three titles tell a thousand words: the recurring metaphor of the bridge connecting the multiple terrain of the borderlands here becomes the woman's body bent over her work, whether this be a piece of writing crafted on the kitchen table or rows of tomatoes waiting to be picked for a pittance. The image retains the positive connotations of mediation, crossing back and forth, while also suggesting sacrifice, surrendering one's back to create the bridge, perhaps connecting women who find themselves isolated in their menial and domestic drudgery. Anzaldúa speaks to working women without idealizing labour or the Southwest, which she openly flees in search of a truer self and a more accepting and satisfying community. She thinks: "I don't have to go back to Texas, to my family of land, mesquites, cactus, rattlesnakes and roadrunners. My family, this community of writers. How could I have lived and survived so long without it. And I remember the isolation, re-live the pain again» (1983: 171). Obviously, she is not escaping the borderland, but the closed horizon. The border is movable and breaks out of the oppression zone occupied by maquiladoras on the south side and plantations on the north. Traditions are selectively re-energized or discarded as the trappings of patriarchal control.

An important strategy adopted by Chicanas to re-conceptualize identity has been to transform Aztlán from a static homeland to a dynamic borderland. The terms "bridge" and "borderland" are highly significant metaphors by which Chicana and Chicano artists evoke a cultural identity based on difference, not just in relation to Anglo-American culture but, within their own hybrid communities. Often this transformative process is fuelled by anger at feeling dispossessed and identified as other, even as traitors to the race, by social factions that struggle to dominate and narrow down the concept of Chicano identity. Anzaldúa's poetry is rich in notions of negotiating a problematic hybrid identity. Writing from her position as a lesbian Mestiza who worked as a farm labourer before achieving wide recognition for her writing, her work defies any literary methodology that would ignore these details of her personal and communal history.

In a poem entitled "To live in the Borderlands means you," identity is denied since the borderlander is characterized by ethnic and racial impurity, similar to Rodriguez's eulogizing of brown «...you / are neither hispana india negra española / ni gabacha, eres mestiza, mulata, half-breed / caught in the crossfire between camps / while carrying all five races on your back / not knowing which side to turn to, run from...» (1987: 194). This poem ends with a call to move beyond all borders and to embody that very ideal: «To survive the Borderlands / you must live sin fronteras / be a crossroads» (1987: 195). The force of Anzaldúa's negation, the rejection of all racial terms implying purity together with the imperative that you must live without borders, poetically enactes Trinh Minh-ha's critique of the Western obsession with identity, based on the concept of «an essential, authentic core that remains hidden to one's consciousness and that requires the elimination of all that is considered foreign or not true to the self». Trinh attributes the compulsion to essentialize, to be authentic, to be «the real Black, Indian or Asian, the real woman» to the Master's logic, designed to divide and conquer (1990: 371). "And in our world», as Audre Lorde has said, «divide and conquer must become define and empower» (91).

Rafael Pérez-Torres comments that Anzaldúa's poem's «interlingual expression and evocation of interstitial spaces represents the power of transgression. The borderlands do not represent merely a cultural or national transgression. As the imagery evoked by the poem suggests, sexual and gender identities give way before the transformative forces of true mestizaje» (Pérez Torres 95). Here he refers to the verses that read: «Cuando vives en la frontera / people walk through you, the wind steals your voice, / you're a burra, buey, scapegoat / [...]/ both woman and man, neither- / a new gender» (1987: 194). Pérez-Torres' interpretation seems overly optimistic and reconciliatory since Anzaldúa does not celebrate that in-between existence in the prophetic tone adopted by Gómez-Peña, for example. Her work bleeds; try as she may to assert the birth of a new gender, a new race: "la Nueva Mestiza," her writing is always haunted by pain that she does not bury like Richard Rodriguez. The source of that pain is not entirely in her rural past. The 


\section{MARTHA NANDORFY}

frustration continues throughout her literary career and also stems from Chicano literary criticism, which according to Pérez-Torres «effects a disenfranchisement felt strongly among gay and lesbian Chicanas/os, among monolingual speakers of English (referring here to those Chicanos who have lost their Spanish or have never learnt it), among the many Chicana writers who were not included among the founding "fathers" of the Chicano Renaissance» (Pérez-Torres 27).

Anzaldúa draws from several Latin American traditions in forging the borderland consciousness of the New Mestiza. In 1966, the Mexican writer José Vasconcelos published a pseudo-scientific text entitled La Raza Cósmica to which Chicanos refer almost unconsciously when calling themselves "raza" (which often means nothing more than "people" in the generic sense). In Gómez-Peña's "Glossary of Borderismos," the term "borderígena" (fusing "border" and "indígena") is defined as «A citizen of the great border region of the Americas, o sea, you \& I and all the pinche raza we know» (1996: 240), "pinche raza" being loosely translatable to "damn folks". More specifically, Vasconcelos forecasts a racial melting pot of cosmic proportions. While he contrasts his theory against «the theory of the pure Aryan defended by the English, and pushed to the aberration imposed by the Nazis» (9), his own discourse is so shockingly prejudiced in both racial and religious terms, that it is hard to believe that it was written in the 1960's and not at the time of the Conquest. He actually predicates his hypothesis: that racial fusion will create a superior cosmic race, on what he claims is the evident backwardness of the Hispanic American people, whom he characterizes as being predominantly indigenous. It is baffling (and convenient for him) that he does not mention Inca, Aztec, Mayan or any other technologically developed cultures. Vasconcelos comes to the conclusion that even the most difficult (i. e. interracial) mestizajes can be elevated to greatness through evangelization: «A religion like Christianity fostered the advancement of Amerindians in just a few centuries, from cannibalism to relative civilization» (13).

Chicano writers and critics often mention The Cosmic Race with explicit reference to Vasconcelos as an important source of inspiration in the formation of Chicano consciousness, but I suspect that the term he coined circulates as pure hearsay due to its positive sound, and is adopted and reconfigured by Chicanos (who have never actually read the book or even the prologue) to cvoke a mestizo solidarity. Another concept that comes into play in Anzaldúa's vision of the New Mestiza is that of the New Man prophesied by Che Guevara and a wide range of writers, including the surrealists and anarchists, who believed that any social revolution must be accompanied by a spiritual revolution, without which individuals are too self-centred to live up to the ideals of socialism. Anzaldúa takes the masculinist image of the New Man and empties it through her poetic negations of the essentialist trappings of self that would inevitably banish the other.

Talk of solidarity can become enmeshed in consensual politics that deny or even persecute difference, and it can also become as vague in terms of actual practice as the notion of universal sisterhood. Border thinking takes us closer to becoming crossroads, open to all the differences that can be bridged and not just tolerated, as Audre Lorde makes clear in speaking out for social transformation through true dialogue that recognizes interdependency:

Advocating the mere tolerance of difference between women is the grossest reformism. It is a total denial of the creative function of difference in our lives. Difference must be not merely tolerated, but seen as a fund of necessary polarities between which our creativity can spark like a dialectic. Only then does the necessity for interdependency become unthreatening. Only within that interdependency of different strengths, acknowledged and equal, can the power to seek new ways of being in the workd generate, as well as the courage and sustenance to act where there are no charters (90).

Such insights are now animating global feminisms to bridge the impasses created by theories and practices that essentialize identity, thereby condemning the identified to solitude. Promoting a sense of helplessness in solitude is one of the aims of globalized capitalism because such a condition is crucial for the successful exploitation of workers, primarily women, whose bodies and labour are now being recolonized given that they do $2 / 3$ of the world's work and earn less than 


\section{BORDER THINKING AND FEMINIST SOLIDARITY IN THE FOURTH WORLD}

$1 / 10$ of its income (Mohanty 235). By joining forces with each other and with more distant others from across the many borders that swing open for business, and slam shut to confine people, women can put into practice feminisms sin fronteras to decolonize and democratize the world. After all, the border, as Anzaldúa reminds us, is home, «but the skin of the earth is seamless. / The sea cannot be fenced, / el mar does not stop at borders» (1987: 3 ).

\section{WORKS CITED}

Anzaldúa, Gloria, ed. Making Face, Making Soul/Haciendo caras: creative and critical perspectives by women of color. San Francisco: Aunt Lute Foundation Books, 1990.

— Borderlands/La Frontera: The New Mestiza. San Francisco: Aunt Lute Books, 1987.

Anzaldúa, Gloria and Cherría Moraga, eds. This bridge called my back: writings by radical women of color. Latham N. Y.: Kitchen Table, Women of Color Press, 1983.

Bhavnani, Kum-Kum ed. Feminism and "Race". London: Oxford UP, 2001.

"CODCO". Wikipedia, the free encyclopedia. 19:52,3 Dec 2004. 31 Dec 2004, <http://en. wikipedia. org/wiki/CODCO>

Fuentes, Carlos. The Buried Mirror: Reflections on Spain and the New World. New York: Houghton Mifflin, 1992.

García, Rupert. Aspects of Resistance. N.Y.: Alternative Museum, 1994.

Gómez-Peña, Guillermo. Warrior for Gringostroika. Saint Paul MN: Graywolf Press, 1989.

- The New World Border: Prophecies, Poems \& Loqueras for the End of the Century. San Francisco: City Lights, 1996.

Gugelberger, Georg M., ed. The Real Thing: Testimonial Discourse and Latin America. Durham: Duke UP, 1996.

Lorde, Audre. "The Master's Tools Will Never Dismantle the Master's House”. Bhavnani, KumKum. Feminism and "Race", 2001.

Moraga, Cherríe. Loving in the War Years. Boston: South End Press, 1983.

Pérez-Torres, Rafacl. Movements in Chicano Poetry: Against Myths, Against Margins. Cambridge, Cambridge UP, 1995.

"Rick Mercer Speaker Profile at the Lavin Agency". Thelavinagency.com. 31 Dec $2004<$ http:// www.thelavinagency.com/canada/rickmercer.html>

Rodriguez, Richard. Brown: The Last Discovery of America. New York: Viking, 2002.

Saldívar, José David. Border Matters: Remapping American Cultural Studies. Berkeley: U California P, 1997.

Talpade Mohanty, Chandra. Feminism Without Borders: Decolonizing Theory, Practicing Solidarity. Durham and London: Duke UP, 2003.

Trinh T. Minh-ha. Framer Framed. New York and London: Routledge, 1992.

"Not You/Like You: Post-Colonial Women and the Interlocking Questions of Identity and Difference". Anzaldúa, ed. Making Face, Making Soul/Haciendo caras, 1990.

Vasconcelos, José. La Raza Cósmica: Misión de la Raza Iberoamericana, Argentina y Brasil. México: Espasa-Calpe Mexicana, 1966. 